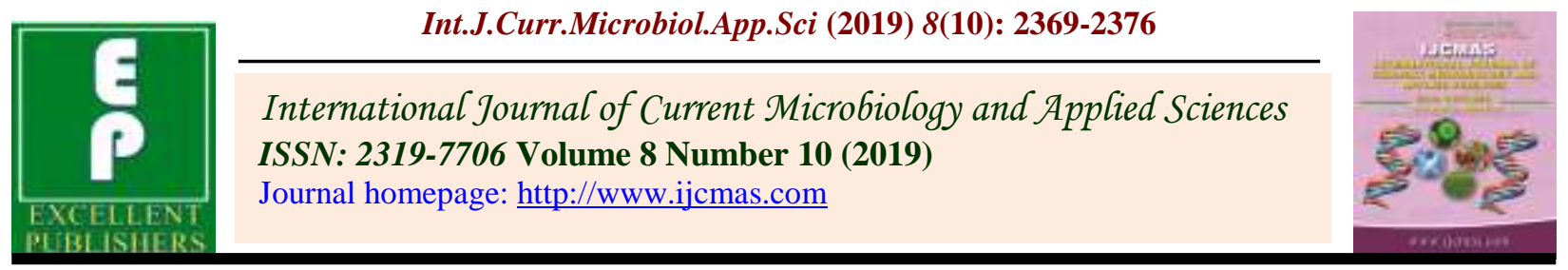

Original Research Article

https://doi.org/10.20546/ijcmas.2019.810.274

\title{
Study the Morphological Characteristics of Udder and Teat and Its Relation with Lactation Milk Yield in Deoni Cattle
}

\author{
Hiremath Basavaraj*, Prashant Waghmare, Vivek M. Patil, M.D. Suranagi, \\ U.S. Biradar, SatishChandra, Anant Rao Desai, H. Mallikarjun and Mithare Prasad \\ Department of Livestock Production and Management, Veterinary College, Bidar Karnataka \\ Veterinary, Animal and Fisheries Sciences University, Bidar, Karnataka (India) \\ *Corresponding author
}

\begin{abstract}
A B S T R A C T
Keywords

Deoni cattle,

Lactation milk

yield,

Morphometric,

Shapes, Teat and

Udder

Article Info

Accepted:

17 September 2019

Available Online:

10 October 2019

The research study was conducted during the year 2018-2019 on 256 Deoni cattle in 13 villages and Livestock Research \& Information Centre (Deoni), Hallikhed (B) in Bidar district of Karnataka state. The study was carried out to find the morphological characteristics of udder and teat and its relation with lactation milk yield (LMY) in deoni cattle which was included in the project "Field Performance Recording of Deoni cattle in Bidar district" as part of Rashtriya Gokul Mission. The strain-wise and parity-wise various shapes of udder and teat were recorded. The finding of the study revealed that overall frequency percentage in shape of the udder was recorded viz; bowl shaped $(49.61 \%)$, goaty shaped $(14.06 \%)$, pendulous shaped $(33.20 \%)$ and round shaped udder $(3.12 \%)$, respectively. Whereas, overall frequency percentage in shape of the teat was recorded viz., bottle shaped (15.62\%), cylindrical (42.96\%), funnel (32.81\%) and pear-shaped teats (8.60\%). Similarly, Bowl shaped udder has highest LMY $(1177.71 \mathrm{~kg})$ followed by goaty $(1134.88 \mathrm{~kg})$, pendulous $(1095.62 \mathrm{~kg})$, while least LMY was recorded in round shaped udder $(976.84 \mathrm{~kg})$. However, cylindrical shape teat has highest LMY $(1211.02 \mathrm{~kg})$ followed by bottle $(1102.42 \mathrm{~kg})$, funnel $(1063.64 \mathrm{~kg})$ and least LMY was recorded in pearshaped teat $(1007.97 \mathrm{~kg})$. The findings of the study over LMY were non-significant effect of udder and teat shape on lactation milk yield.
\end{abstract}

\section{Introduction}

Milk yield is an important selection criterion in dairy cattle. Some anatomical attributes are considered related to milk production. The udder of the cow is one of the most important criteria used to predict production performance. A large sized udder with large proportion of glandular tissue and a symmetrical shape is an asset to milch animals. The udder characteristics were reported to be important in relation to milk production, where production records were lacking (Akhtar and Thakuria 1998). Udder is the first site inspected while judging of dairy cattle by farmers for assessing the milking 
ability of animals. Therefore, it is more important to have knowledge of morphology of udder and teat shapes and its relation with milk yield. Indian cattle breeds are described on the basis of colour, shape, body size, horn but very little information is available on udder characteristics. In India, systematic data on type and conformation of udder and teat are not available for different breeds. The size and shape of udder are very important conformation traits which could play a vital role for the suitability of economical milk production and should be considered for selecting dairy animals (Bhuiyan et al., 2004). A roomy udder is a prerequisite for high milk production (Ahmed and Barbary 2000). Whereas, pendulous udders are more susceptible to injuries, mastitis and more difficult to milk through milking machine (Sagar et al., 2009). It is presumed that the size and morphology of udder varies greatly from individual to individual animal and between different lactation orders (Bharti et al., 2015). The size and form of udder and teats not only influence milk production, but also differ in their suitability for milking (Bardakcioglu et al., 2011).

\section{Materials and Methods}

The research study was conducted during year 2018-2019 on 256 Deoni cattle in 13 villages and Livestock Research \& Information Centre (Deoni) in Bidar district. The study was carried out to find the morphological characteristics of udder and teats and its relation with lactation milk yield in Deoni cattle, which was included in the project "Field Performance Recording of Deoni cattle in Bidar district" as part of Rashtriya Gokul Mission. The strain-wise and parity-wise various shapes of udder, teat and lactation milk yield were recorded. Shape of udder was determined through visual appraisal method adopted by Cerkascenko et al., (1958) and accordingly categorized into different types, viz., Bowl, Goaty, Pendulous and Round.
Whereas, shape of teats was observed grossly and categorized into different types, viz., Bottle, Cylindrical, Funnel and Pear-shaped teats as per the visual appraisal method followed by Ovesen et al., (1972). Statistical analysis was done using SAS software version 9.3 (2010) using General Linear Model (GLM) procedure.

\section{Results and Discussion}

\section{Strain-wise and Parity-wise frequency of different udder shapes in Deoni cattle}

In present study the observation regarding udder shape, found that bowl shaped udder was observed more predominant, followed by pendulous and goaty shaped udder. Whereas, round shaped udder was found least among all strain and parities of Deoni cattle. The overall frequencies of bowl (49.61\%), goaty $(14.06 \%)$, pendulous $(33.20 \%)$ and round shaped udder $(3.12 \%)$ were recorded respectively. The udder shape plays an important role in selection of high milk yielding cattle and the different shapes and size of the udder might be its genetic heritability (Liebenberg and Jannermann 1958). Similar findings were also reported by Kadam (2018) in Deoni cattle in Maharashtra with frequency of bowl-shaped udder being 52.25 per cent. However, the frequencies of the other udder shapes varied: pendulous $(28.00 \%)$, goaty $(2.75 \%)$ and round $(17.00 \%)$. Similar study was conducted and reported in different breeds of the cattle by various researchers viz, Sharma 1967 reported that, high frequency of bowl-shaped udder was observed in Hariana (93\%) and Tharparkar cows $(70.9 \%)$ respectively. Similarly, findings are also confirmed by Tripathi et al., (1982), Saiyed (1987), Prajapati et al., (1995), Kamboj et al., (2007), Danish et al., (2018) and Manoj (2018). Contrary to the present study, Singh et al., (1997) reported that high frequency of round shaped udder $(72 \%)$ was observed in crossbred cow. However, in 
Ongole cattle high frequency of goaty shaped udder (59.18\%) was reported by Sampathkumar (2018). The strain-wise and parity-wise observed frequencies of various udder shapes are given in Table $1 \& 2$ respectively and shown in Figure 1.

\section{Strain-wise and Parity-wise frequency of different teat shapes in Deoni cattle}

In present study the observation regarding teat shape found that cylindrical shaped teat was observed more predominant, followed by funnel and bottle shaped teat. Whereas, pear shaped teat was found least among all strain and parities of Deoni cattle. The overall frequencies of Bottle (15.62\%), Cylindrical (42.96\%), Funnel (32.81\%) and Pear-shaped teat $(8.60 \%)$ were recorded respectively. The teat shape plays an important role in milk flow or let-down of milk from the udder, which also helps in selection of high milk yielding cattle and the different shapes of the teat might be its genetic heritability. Similar findings were reported by Kadam (2018) in Deoni cattle in Maharashtra with frequency of cylindrical shaped teat being 57.75 per cent. However, the frequencies of the other teat shapes varied: bottle (2.25\%), funnel $(29.75 \%)$ and pear $(10.75 \%)$ respectively. Similar study was conducted and reported comparable and high frequency of cylindrical shaped teatin different breeds of the cattle by various researchers viz., Tripathi et al., (1982) reported that comparable frequency of cylindrical shaped teat (39\%) was observed in Gir cows, Saiyed (1987) as $83.73 \%$ in Jersey $x$ Kankrej. Whereas, findings were also confirmed by Sampathkumar (2018) and Manoj (2018) in Ongole (57.82\%) and Red Kandharicattle (43.50\%), respectively. Contrary to the present study, Bhosrekar and Nagpaul (1971) reported that high frequency of funnel shaped teat $(78.19 \%)$ in crossbred cows. However, Kamboj et al., (2007) reported that funnel shaped teats were 48.27 $\%$ in Karan-Fries cows. Similar findings are also confirmed by Patel et al., (2018) and Danish et al., (2018) in crossbred (48.63\%) and Sahiwal cows $(58.82 \%)$ respectively. The observed strain-wise and parity-wise frequencies of different teat shapes in Deoni cattle are given in Table $3 \& 4$ respectively and shown in Figure 2.

Table.1.Strain-wise frequency of different udder shapes in Deoni cattle

\begin{tabular}{|c|c|c|c|c|c|c|c|c|c|}
\hline Strain & Bowl & \% & Goaty & \% & Pendulous & \% & Round & \% & Total \\
\hline Wannera & 40 & 52.64 & 14 & 18.42 & 21 & 27.63 & 1 & 1.31 & $\mathbf{7 6}$ \\
\hline Shevera & 68 & 50.38 & 14 & 10.37 & 48 & 35.55 & 5 & 3.70 & $\mathbf{1 3 5}$ \\
\hline Balankya & 19 & 42.22 & 8 & 17.78 & 16 & 35.55 & 2 & 4.45 & $\mathbf{4 5}$ \\
\hline Overall & $\mathbf{1 2 7}$ & $\mathbf{4 9 . 6 1}$ & $\mathbf{3 6}$ & $\mathbf{1 4 . 0 6}$ & $\mathbf{8 5}$ & $\mathbf{3 3 . 2 0}$ & $\mathbf{8}$ & $\mathbf{3 . 1 2}$ & $\mathbf{2 5 6}$ \\
\hline
\end{tabular}

Table.2 Parity-wise frequency of different udder shapes in Deoni cattle

\begin{tabular}{|c|c|c|c|c|c|c|c|c|c|}
\hline Parity & Bowl & \% & Goaty & \% & Pendulous & \% & Round & \% & Total \\
\hline $\mathbf{1}$ & 17 & 62.97 & 6 & 22.22 & 4 & 14.81 & 0 & 0 & $\mathbf{2 7}$ \\
\hline $\mathbf{2}$ & 20 & 39.21 & 12 & 23.52 & 18 & 35.30 & 1 & 1.96 & $\mathbf{5 1}$ \\
\hline $\mathbf{3}$ & 24 & 60.00 & 3 & 7.50 & 11 & 27.50 & 2 & 5.00 & $\mathbf{4 0}$ \\
\hline $\mathbf{4}$ & 20 & 44.45 & 5 & 11.11 & 18 & 40.00 & 2 & 4.44 & $\mathbf{4 5}$ \\
\hline $\mathbf{5}$ & 17 & 37.78 & 6 & 13.33 & 19 & 42.22 & 3 & 6.67 & $\mathbf{4 5}$ \\
\hline $\mathbf{6}$ & 16 & 59.26 & 2 & 7.40 & 9 & 33.34 & 0 & 0.00 & $\mathbf{2 7}$ \\
\hline $\mathbf{7}$ & 13 & 61.90 & 2 & 9.52 & 6 & 28.57 & 0 & 0.00 & $\mathbf{2 1}$ \\
\hline Overall & $\mathbf{1 2 7}$ & $\mathbf{4 9 . 6 1}$ & $\mathbf{3 6}$ & $\mathbf{1 4 . 0 6}$ & $\mathbf{8 5}$ & $\mathbf{3 3 . 2 0}$ & $\mathbf{8}$ & $\mathbf{3 . 1 2}$ & $\mathbf{2 5 6}$ \\
\hline
\end{tabular}


Table.3 Strain-wise frequency of different teat shapes in Deoni cattle

\begin{tabular}{|c|c|c|c|c|c|c|c|c|c|}
\hline Strain & Bottle & \% & Cylindrical & \% & Funnel & \% & Pear & \% & Total \\
\hline Wannera & 9 & 11.84 & 35 & 46.05 & 27 & 35.52 & 5 & 6.58 & $\mathbf{7 6}$ \\
\hline Shevera & 23 & 17.03 & 54 & 40.00 & 42 & 31.11 & 16 & 11.86 & $\mathbf{1 3 5}$ \\
\hline Balankya & 8 & 17.78 & 21 & 46.66 & 15 & 33.33 & 1 & 2.23 & $\mathbf{4 5}$ \\
\hline Overall & $\mathbf{4 0}$ & $\mathbf{1 5 . 6 2}$ & $\mathbf{1 1 0}$ & $\mathbf{4 2 . 9 6}$ & $\mathbf{8 4}$ & $\mathbf{3 2 . 8 1}$ & $\mathbf{2 2}$ & $\mathbf{8 . 6 0}$ & $\mathbf{2 5 6}$ \\
\hline
\end{tabular}

Table.4 Parity-wise frequency of different teat shapes in Deoni cattle

\begin{tabular}{|c|c|c|c|c|c|c|c|c|c|}
\hline Parity & Bottle & \% & Cylindrical & \% & Funnel & \% & Pear & \% & Total \\
\hline $\mathbf{1}$ & 1 & 3.70 & 8 & 29.63 & 11 & 40.74 & 7 & 25.92 & $\mathbf{2 7}$ \\
\hline $\mathbf{2}$ & 9 & 17.64 & 21 & 41.18 & 18 & 35.29 & 3 & 5.88 & $\mathbf{5 1}$ \\
\hline $\mathbf{3}$ & 8 & 20.00 & 15 & 37.50 & 10 & 25.00 & 7 & 17.50 & $\mathbf{4 0}$ \\
\hline $\mathbf{4}$ & 7 & 15.55 & 20 & 44.44 & 18 & 40.00 & 0 & 0.00 & $\mathbf{4 5}$ \\
\hline $\mathbf{5}$ & 8 & 17.78 & 19 & 42.22 & 14 & 31.11 & 4 & 8.89 & $\mathbf{4 5}$ \\
\hline $\mathbf{6}$ & 5 & 18.52 & 13 & 48.15 & 8 & 29.62 & 1 & 3.70 & $\mathbf{2 7}$ \\
\hline $\mathbf{7}$ & 2 & 9.52 & 14 & 66.66 & 5 & 23.80 & 0 & 0.00 & $\mathbf{2 1}$ \\
\hline Overall & $\mathbf{4 0}$ & $\mathbf{1 5 . 6 2}$ & $\mathbf{1 1 0}$ & $\mathbf{4 2 . 9 6}$ & $\mathbf{8 4}$ & $\mathbf{3 2 . 8 1}$ & $\mathbf{2 2}$ & $\mathbf{8 . 6 0}$ & $\mathbf{2 5 6}$ \\
\hline
\end{tabular}

Table.5 Udder shape-wise least square means of lactation milk yield (kg)

\begin{tabular}{|c|c|}
\hline Udder Shapes & Lactation milk yield \\
\hline Bowl & 1177.71 \\
\hline Goaty & 1134.88 \\
\hline Pendulous & 1095.62 \\
\hline Round & 976.84 \\
\hline Overall & $1173.77 \pm 33.868$ \\
\hline
\end{tabular}

Table.6 Teat shape-wise least square means of lactation milk yield (kg)

\begin{tabular}{|c|c|}
\hline Teat Shapes & Lactation milk yield \\
\hline Bottle & 1102.42 \\
\hline Cylindrical & 1211.02 \\
\hline Funnel & 1063.64 \\
\hline Pear & 1007.97 \\
\hline Overall & $1173.77 \pm 33.868$ \\
\hline
\end{tabular}


Fig.1 Different Shape of Udder

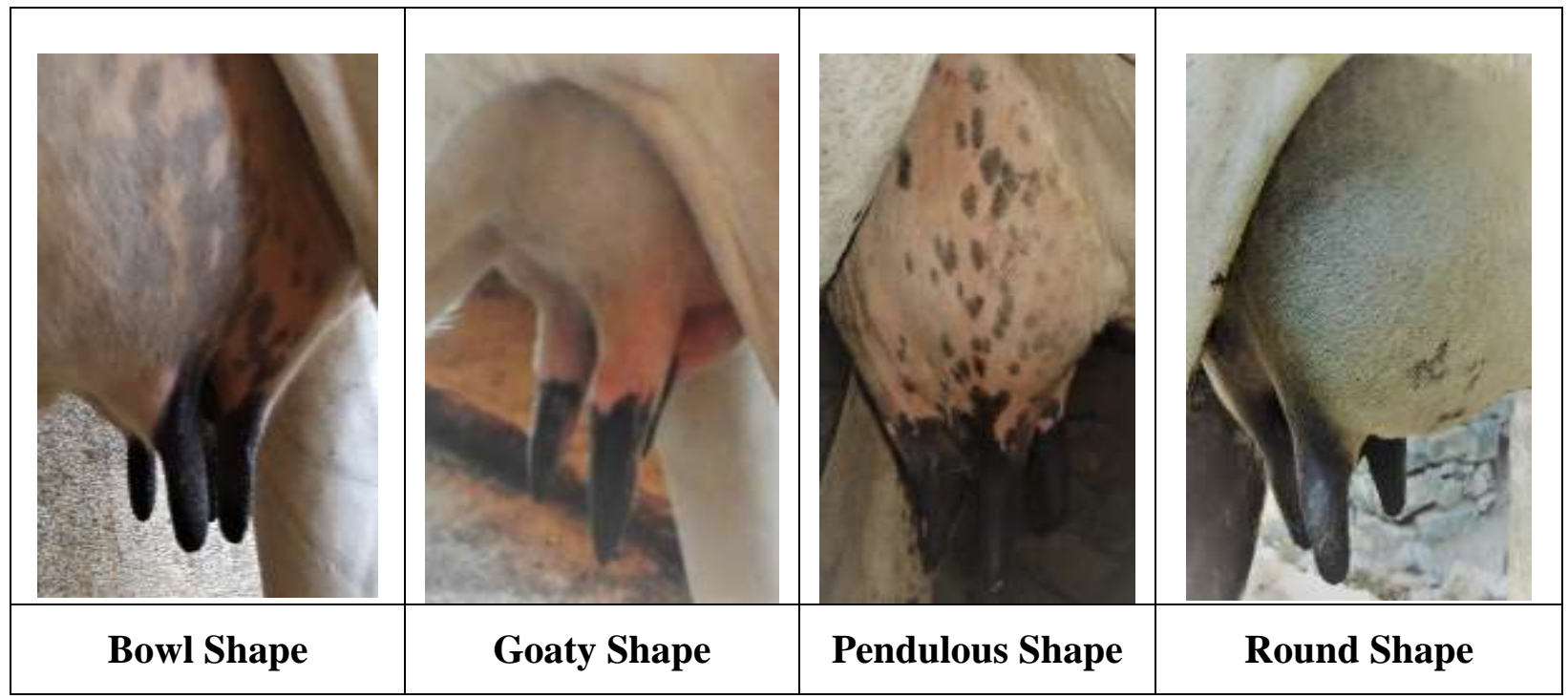

Fig.2 Different Shape of Teat

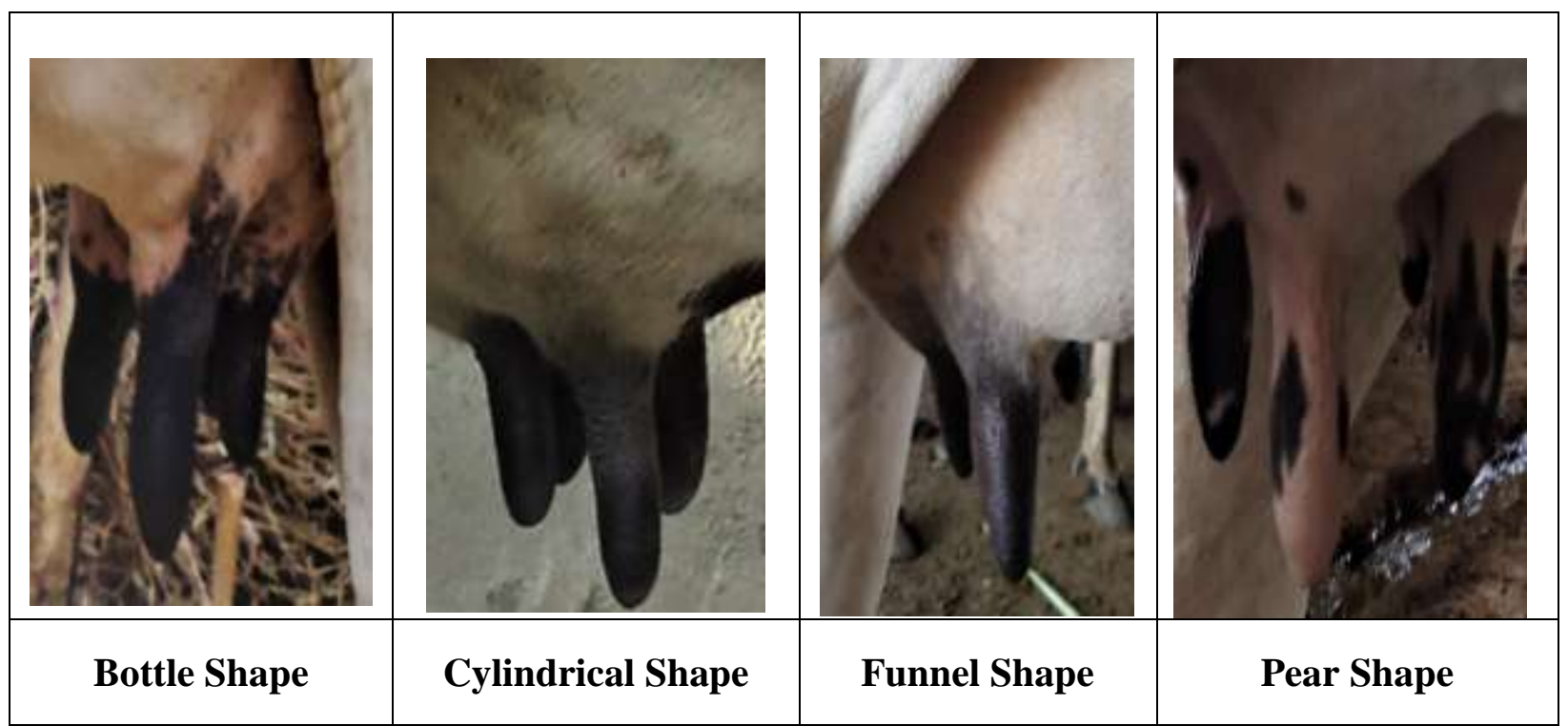

The udder and teat shape-wise lactation milk yield (LMY) in Deoni cattle

In present study the regarding lactation milk yield (LMY) in Deoni cattle observed that, Bowl shaped udder has highest LMY $(1177.71 \mathrm{~kg})$ followed by goaty $(1134.88 \mathrm{~kg})$ and pendulous shaped udder (1095.62 kg), while least LMY was recorded in round shaped udder (976.84 kg). However, cylindrical shape teat has highest LMY $(1211.02 \mathrm{~kg})$ followed by bottle $(1102.42 \mathrm{~kg})$, funnel $(1063.64 \mathrm{~kg})$ and least LMY was recorded in pear- shaped teat $(1007.97 \mathrm{~kg})$. The findings of the study over LMY were non-significant effect of udder and teat shape on lactation milk yield. In present study overall lactation milk yield was found to be 
$1173.77 \pm 33.868 \mathrm{~kg}$. Comparable LMY $(1193.22 \pm 44.79 \mathrm{~kg})$ in Deoni cattle was reported by Gatchearle et al., (2009). Similarly, Das et al., (2012) (911.14 kg), Kuralkar et al., (2014) (910.95 $\pm 27.62 \mathrm{~kg})$, Patil (2014) (881.35 $\pm 37.64 \mathrm{~kg})$, Saravanan et al., (2015) $(824.44 \pm 149.99 \mathrm{~kg})$ and Basak and Das (2018) $(819.98 \pm 16.50 \mathrm{~kg})$. However, lower LMY in Deoni cattle reported by Thombre et al., (2001) $(518.23 \pm 22.44 \mathrm{~kg})$, Chakravarthi et al., (2002) (238.86 \pm 76.00 $\mathrm{kg})$, Bhutkar et al., (2014) $(358.31 \pm 27.18 \mathrm{~kg})$ and Shingare et al., (2015) (236.43 \pm 12.71 $\mathrm{kg}$ ). The udder and teat shape-wise lactation milk yield of Deoni cattle is given in Table 5 and 6 , respectively.

In conclusion, Bowl shaped udders were the predominant shape in Deoni cattle and other cattle breeds. Pendulous udders were more common in fourth and fifth parities, which could be explained by the loosening of udder ligaments with age. A pendulous udder with poorly spaced teats is thick, prone to ballooning and could result in poor suckling and possibly increased calf mortality. Cylindrical shaped teats were the predominant shape in Deoni cattle and other cattle breeds and common in sixth and seventh parities. The uneven shaped teats will cause calf suckling problems and mortalities. Poor teat shape and texture leads to injury causing scar tissue and reduced milk flow. Bowl shaped udder and cylindrical shape teat has highest LMY. Therefore, impact of udder and teat shape is very important criteria for selection of high milk yielding Deoni cattle.

\section{References}

Ahmed, S. And Barbary, E., (2000). Dairy and meat cattle. College of Agric., Univ. of Alexandria, Egypt, Dar ElMaarif Printing Press. pp 73.

Akhtar, N. and Thakuria, K., (1998). Milk production in relation to variation in size and shape of udder in Swamp buffaloes. Indian J. Anim. Sci., 68(12): 1281-1283.

Bardakcioglu, H.E., Sekkin, S. and Oraltoplu, H.D., (2011). Relationship between some teat and body measurements of Holstein cows and sub-clinical mastitis and milk yield. J. Anim. Vet. Adv., 10(13): 1735-1737.

Basak, S. And Das, D.N. (2018). Effect of parity, period and season of calving on production and reproduction traits on Deoni cattle. J. Anim. Health Prod., 6(1): 1-4.

Bharti Praveen, A.K.S., Tomar, M.R., Verma, P.K., Bharti. and Braj Pal Singh. (2015). Effect of lactation order on morphological traits of teat and udder in Murrah Buffaloes. Journal of Animal Research. 5(3): 561-565.

Bhosrekar, M.R. and Nagpaul, P.K., (1971). Types of udders and teats in some Indianmilch breeds of cattle and buffaloes as compared to those of crossbreds. Indian J. dairy science. 24 (4): 208-211.

Bhuiyan, M.M., Islam, M.R., Ali, M.L., Hossain, M.K., Kadir. M.A., Lucky, N.S. and Das, B.R., (2004). Importance of mammary system conformation traits in selecting dairy cows on milk yield in Bangladesh. J. Biol. Sci., 4(2): 100-102.

Bhutkar, S.S., Thombre, B.M. and Bainwad, D.V. (2014). Effect of non-genetic factors on production traits in Deoni cows. J. Agri. Vet. Sci., 7(12): 9-14.

Cerkascenko, I. (1958). Mol. Mjasn. Zivotn. 3: 36. (Anim. Breed. Abstr. 1958, 26, 264).

Chakravarthi, M.K.,Sasidhar, P.K.V. And Reddy, Y.R. (2002). Productive and reproductive performance of Deoni cattle. Indian. J. Dairy Sci., 55(1): 5657.

Danish Ziaullah, Mukesh Bhakat, Paray, A.R., Shabir Ahmad Lone., Abdul 
Rahim, Mohanty and Ranjana Sinha (2018). Udder and teat morphology and their relation with incidence of subclinical mastitis in Sahiwal, Karan Fries cows and Murrah buffaloes. Journal of Entomology and zoology studies. 6(5): 2138-2141.

Das, D.N., Jeyakumar, S., Ramesha, K.P., Srinivas, B. and Kataktalware, M. (2012). Deoni cattle: A dual-purpose breed of southern India. In NDRI News., 17(3): 15-16

Gatchearle, P.L., Mitkari, K.R., Mule, R.S., Baswade, S.V. and Adangale, S.B. (2009). Effect of age at first calving on lactation milk yield and lactation length. Indian J. Anim. Res., 43(3): 228-229.

Kadama, A.V (2018). Relationship of size and shape of udder and teats with milk yield in Deoni cattle of Latur district. M.Sc. (Agri) thesis, MAU, Parbhani, Maharashtra, India.

Kamboj, M.L., Anshan Singhand Shiv Prasad. (2007). Effect of udder and teat shapes and their measurements on somatic cell counts in milk of Karan-Fries cows. Research Journal of Animal Husbandry and Dairy Science. 60(6): 435-440.

Kuralkar, S.V., Bankar, P.S., Chopade, M.M., Kuralkar. P and Dhaware, S.A (2014). Phenotypic characteristics, production and reproduction performance of Deoni cattle in its native tract. Ind. J. Anim. Sci., 84(1): 75-77.

Liebenberg, O. and Jannermann, I. (1958). The influence of breeding on udder shape and size. Dairy Sci. Abst. 20:744, pp 288.

Manoj, H., (2018). Relationship of size and shape of udder and teats with milk yield in Red Kandhari cattle of Nanded district. M.Sc. (Agri) theses, Vasantrao Naik Marathwada Agricultural University, Parbhani, Maharashtra, India.
Ovesen, E. (1972). Milking ability in relation to size and shape of teats. Anim. Prod., 15(3): 251-257.

Patel Y.G. and Trivedi, M.M. (2018). Morphometric characteristics of udder and teat in crossbred cows. International Journal of Livestock Research. 8(6): 251-257.

Patil. V.M (2014). Critical appraisal of the management practices of Deoni Cattle in Bidardistrict. Ph.D.thesis, KVAFSU, Bidar, India.

Prajapati, K.B., Ashwar, J.P., Patel, J.P., Patel J.B. and Singh, D.V (1995). Size and shape of udder and teats in Kankrej cows. Indian J. Anim. Prod. Mgmt., 11(1): 43-48.

Sagar, P.V. (2009). Congenital absence of teats (Athelia) in a buffalo. Buffalo Bulletin. 28(3): 97-100.

Saiyed, L.H (1987). Biometrics of certain body parts in relation to body weight and milk production in Jersey $\mathrm{x}$ Kankrej crossbreds. M.V.Sc. thesis, Gujarat Agricultural University, Anand, India.

Sampath Kumar, B (2018). A study on association of morphometric characters with certain economics traits in Ongole cattle. M.V.Sc. theses, Sri Venkateshwara Veterinary University, Tirupati, India.

Saravanan, R., Das, D.N., De, S. and Panneerselvam, S. (2015). Effect of season and parity on somatic cell count across zebu and crossbred cattle population. Indian J. Anim. Res., 49(3): 383-387.

Sharma, B.D. (1967). Studies on variation in shape and size of udder in grey breed of Indian cattle. M.V.Sc. theses, Agricultural University, Agra, India.

Shingare, D.S., Chauhan, B.R., Bhiseand Ghosh, N. (2015). Estimatesof genetic parameters and trends of lactation performance traits of Deonicattle. Theriogenology Insight., 5(2): 69-79. 
Singh, S.K., Pandey, H.S., Suman, C.L. and Saxena, M.M. (1997). Milk ability and milk flow rate in relation to udder and teat shapes of crossbred cows. Indian J. Anim. Prod. Mgmt., 13(1): 13-18.

Thombre, B.M., Mitkari, K.R., Patil, G.R. And Jadhav, V.S. (2001). Age at first calving effect on economic traits in
Deoni cattle of Maharashtra. Indian $J$. Anim. Res., 35(1): 65-67.

Tripathi, G.S., Koul, G.L. and Katpatal, B.G. (1982). Biometrical studies on shape and size of udder and teats and their relation with milk yield in Gir cattle. Indian J. Dairy Sci., 35(4): 539-543.

\section{How to cite this article:}

Hiremath Basavaraj, Prashant Waghmare, Vivek M. Patil, M.D. Suranagi, U.S. Biradar, Satish Chandra, Anant Rao Desai, H. Mallikarjun and Mithare Prasad. 2019. Study the Morphological Characteristics of Udder and Teat and Its Relation with Lactation Milk Yield in Deoni Cattle. Int.J.Curr.Microbiol.App.Sci. 8(10): 2369-2376. doi: https://doi.org/10.20546/ijcmas.2019.810.274 